Int. Archs Allergy appl. Immun. 1987;83:I-V

\title{
Contents, Vol. 83, 1987
}

\section{No. 1}

Original Paper

Human Interleukin-3-Like Activity, Basophil and Eosinophil

Growth Promoting Activities and Colony Stimulating Fac

tor Derived from Several Cell Lines

Tanno, Y.; Stadler, B.; Denburg, J.A 1

Eosinophil Response in Mast Cell-Deficient W/Wv Mice

Nawa, Y.; Owhashi, M.; Imai, J.; Abe, T 6

Effect of Schistosome-Derived Inhibitory Factor on the Cell Cycle of T Lymphocytes

Mazingue, C; Walker, C; Domzig, W.; Capron, A.; De

Week, A.; Stadler, B.M 12

Isolation of Interleukin-1 from Human Milk

Söder, 0

19

Thermostable Ethanol-Insoluble Antigens of Human Heart Muscle Kaise, S.; Abeyounis, C.J.;

Kaplan, M.H.; Milgrom, F. . . 24

Involvement of Serotonin in Intestinal Mastocytopoiesis and

Inflammation during a Trichinella spiralis Infection in Mice

Parmentir, H.K.; de Vries, C; Ruitenberg, E.J.; Van

Loveren, $\mathrm{H} \quad 31$

Effects of Some Prostaglandins and Leukotrienes on Lympho

cytes, Monocytes and Their Activity in vitro

Wasserman, J.; Hammarström, S.; Petrini, B.; Blomgren,

H.; von Stedingk, L.-V.; Vedin, 139

Immunogenicity and Tolerogenicity of a Major House Dust

Mite Allergen, Der p I from Dermatophagoides pteronyssi-

nus, in Mice and Rats

Stewart, G.A.; Holt, P.G 44

Histochemical and Functional Characteristics of the Human

Nasal Mast Cell

Gomez, E.; Corrado, O.J.; Davies, R.J 52

Purification, Identification and Elimination of a Natural $\mathrm{Hu}$

man Serum Antibody with Cytotoxic Effect on Guinea Pig

Thymocytes

Sandberg, G.; Rydlander, L.; Stenvinkel, C 57

A Sandwich Enzyme Immunoassay for the Detection of $\mathrm{Hu}$ man IgG Antibodies to Dog Allergens

Viander, M.; Nieminen, E.; Valovirta, E.; Vanto, T.; Inge-

man, L.; Koivikko, A 64 
E-Rosetting of Guinea Pig Lymphocytes with Lyophilized Rabbit Red Cells after Treatment with Papain and Glutaral-dehyde

Ota, F.; Ono, M.; Uegaki, K.; Akiyama, Y.; Satomi, Y.;

Fukui, K $\quad 72$

In vitro Effect of Alpha-Interferon on Mononuclear Cells of Normal and Autoimmune Patients Attallah, A.M.; Steinberg, A.D.; Clark, H.W.; Brown,

T.McP.; Metwali, A.; Fleisher, T.A 77

Early Immunological Prediction of Renal Allograft Rejection

Attallah, A.M.; Abdelghaffar, H.; Fawzy, A.; Alghraoui,

F.; Alijani, M.R.; Mahmoud, L.A.; Ghoneim, M.A.; Helf-

rich, G.B 83

Binding of Monoclonal IgM Rheumatoid Factor to Strepto

cocci via the Antibody Combining Site

Schroder, A.K.; Gharavi, A.E.; Steinitz, M.; Johansson,

P.J.H.; Christensen, P 88

Lymphokine Production by T Cells Generated during Infec

tion with Trichinella spiralis

Grencis, R.K.; Riedlinger, J.; Wakelin, D 92

Distribution of a Major Allergen of Rye Grass (Lolium per-

enne) Pollen between Other Grass Species

Standring, R.; Spackman, V.; Porter, S.J 96

Increased Production of Antibodies to Spermatozoa and Sem

inal Fluid in Rabbits Used as Semen Donors

Wicher, V.; Wicher, K.; Gruhn, R.F 104

Short Communication

Presence of la-Positive Cells in the Central Nervous System of

the Rat during Various Pathological Conditions

Polman, C.H.; Dijkstra, CD.; de Groot, C.J.A.; Koetsier,

J.C.; Sminia, T 109

Book Review 112

News Item 112

Erratum 112

No. 2

Original Paper

Immune Response to Bee Venom. II. Quantitation of the

Absolute Amounts of IgE and IgG Antibodies by Satura

tion Analysis

Kemeny, D.M.; Lessof, M.H 113

Direct Modulation of Human Neutrophil Adherence by Coag-

gregating Periodontopathic Bacteria

Seow, W.K.; Seymour, G.J.; Thong, Y.H 121

Alterations in the Proliferative Responses of T Cells from Aged and Chimeric Mice Iwashima,

M.; Nakayama, T.; Kubo, M.; Asano, Y.; Tada, T. 129

Influence of xid on Anti-Azophenylarsonate (Ar) Antibody

Responses of (CBA/N X A/J)Fi Mice: Differential Idotype 
Expression Induced by Only One of Two Ar Antigens

Conger, J.D 138

IV

Contents

Isolation of Two Immunogenically Different Allergens from

Schistosoma japonicum Eggs

Owhashi, M.; Horii, Y.; Ishii, A.; Nawa, Y 149

Detection of Antigliadin Antibodies in Bullous Diseases and Their Recognition of Similar

Antigenic Polypeptides Kumar, V.; Jain, N.; Beutner, E.H.; Chorzelski, T.P. ... 155

Expression of Heterophile, Paul-Bunnell and Hanganutziu-Deicher Antigens on Human

Melanoma Cell Lines Nakarai, H.; Saida, T.; Shibata, Y.; Irie, R.F.; Kano, K. . 160

Interleukin-2 Responses of MRL/lpr Mouse Splenocytes and

Lymph Node Cells Induced by TPA and A23187

Katagiri, T.; Tomiyama, H.; Kyuwa, S.; Kano, K 167

Protection against Experimental Allergic Encephalomyelitis

with Complete Freund's Adjuvant Is Unaffected by Ioniz

ing Irradiation

Weber, F.; Hempel, K 174

Infectious Mononucleosis: Increase of High-Affinity E-Recep-

tor-Bearing Lymphocytes

Næss, A.; Talstad, I.; Solberg, CO 178

Glycoprotein Allergens in Pollen of Timothy. III. Immuno-

chemical and Biological Properties of a Basic Glycoprotein

Haavik, S.; Bryhni Frostad, A.; Smestad Paulsen, B.;

Wold, J.K 182

Enhanced Mitogenic Reactivity of Human T Cells after Pas

sage through the Thymus. Response to Phytohemagglu-

tinin and Mercuric Chloride

Nordlind, K; Ernström, U.; Henze, A 190

T Cell Activation Surface Markers and Autologous Mixed Lymphocyte Reaction Do Not Differ in True and Pseudo Food Allergy

Dirienzo, W.; Ciprandi, G.; Caria, M.; Scordamaglia, A.;

Bagnasco, M.; Canonica, G.W.; Fudenberg, H.H 193

Interactions between Granulocytes and Platelets with the Guinea-Pig Lung in Passive

Anaphylactic Shock. Correlations with PAF-Acether-Induced Lesions Lellouch-Tubiana, A.;

Lefort, J.; Pfister, A.; Vargaftig, B.B. 198

Short Communications

The Effect of Rheumatoid Factor on the Clearance of Endoge

nous Immune Complexes Formed in Low-Affinity Mice

during the Induction of Immune Complex Disease

Devey, M.E.; Hogben, D.N 206

Induction of Antiphosphocholine Antibodies Utilizing

Lambda Light Chains in BALB/c Mice

Hall, T.J 210 
Reactivity of Two Major Allergens Isolated from Schistosoma japonicum Eggs against IgE and IgG Antibodies in Human

Serum

Owhashi, M.; Horii, Y.; Ishii, A.; Nawa, Y 213

Monitoring of Antibodies in Patients on Immunotherapy with

Insect Venoms by Immunoblotting

Einarsson, R 217

Tolerance to Orally Induced Anaphylactic Sensitisation to

Cow's Milk Proteins and Patency of the Intestinal Mucosa

in the Neonatal Guinea Pig

Weaver, L.T.; Koritz, T.N.; Coombs, R.R.A 220

Book Reviews

223

News Item 224

No. 3

Original Paper

Glycoprotein Allergens in Pollen of Timothy. IV. Structural

Studies of a Basic Glycoprotein Allergen

Haavik, S.; Smestad Paulsen, B.; Wold, J.K 225

Glycoprotein Allergens in Pollen of Timothy. V. Significance

of the Carbohydrate Moiety for the Immunological Activ

ity of a Basic Glycoprotein Allergen

Haavik, S.; Smestad Paulsen, B.; Wold, J.K 231

Ectophospholipase A2 Activity of the Rabbit Peritoneal Neu-

trophil

Kennedy, S.P.; Becker, E.L 238

Synergistic Enhancement of Mitogen Responses of Human

Lymphocytes by Inhibitors of Cyclo-Oxygenase and 5,8,11-

Eicosatriynoic Acid, an Inhibitor of 12-Lipoxygenase and

Leukotriene Biosynthesis

Blomgren, H.; Hammarström, S.; Wasserman, J 247

Immunological Effects of Ciclosporin in Primary Biliary Cirrhosis: Suppression of Activated T

Cells and Autoantibody Levels

Karlsson-Parra, A.; Tötterman, T.H.; Nyberg, A.; Mendel-

Hartvig, I.; Lööf, L.; Forsum, U 256

Primary Biliary Cirrhosis: Antigenic Specificity of IgM-Type

Mitochondrial Antibodies Analyzed by Immunoblotting

and ELISA

Mendel-Hartvig, I.; Frostell, Å.; Tötterman, T.H 265

Soy- and Shrimp-Specific IgE Responses in Orally and Intra-peritoneally Immunized Mice

Bozelka, B.E.; Carrow, E.; Pahud, J.-J.; Lehrer, S.B. ... 271

Cell-Mediated Immunity and Biological Response Modifiers in Insulin-Dependent Diabetes

mellitus Complicated by End-Stage Renal Disease

Attallah, A.M.; Abdelghaffar, H.; Fawzy, A.; Alghraoui,

F.; Alijani, M.R.; Mahmoud, L.A.; Ghoneim, M.A.; Helf-

rich, G.B 278

Effect of Azelastine on the Release and Action of Leukotriene C4 and D4 
Katayama, S.; Tsunoda, H.; Sakuma, Y.; Kai, H.; Tanaka, I.;

Katayama, K 284

Eosinophil Chemotactic Lymphokine Produced by Spleen

Cells of Schistosoma japonicum-lnfccled Mice. II. Physico-

chemical Heterogeneity of Eosinophil Chemotactic Lym-

phokines Selective to Bone Marrow- or Peritoneal Exu-

date-Eosinophils

Owhashi, M.; Nawa, Y 290

New Immunomodulator Lobenzarit Disodium (CCA): Activa

tion of IgE Class-Specific Suppressor T Lymphocytes and

Regulation of IgE Antibody Response Enhanced by Sub-

lethal X-Irradiation in SJL/J Mice

Yamashita, Y.; Nakano, T.; Ohsugi, Y 296

Inhibitory Immunization Using Complete Freund's Adjuvant

on Ongoing Eosinophilia Induced by Repeated Antigen-

Stimulations in Guinea Pigs

Kasuya, S.; Otsuka, S.; Kano, S.; Ohtomo, H

Immunogenicity of Acrylate Chemicals as Assessed by Anti

body Induction

Bull, J.E.; Henderson, D.C.; Turk, J.L 310

Contents

$\mathrm{V}$

A Factor Potentiating Antibody Formation Spontaneously

Produced by Splenic T Cells of MRL/MP-lpr/lpr Mice

Ashiba, T.; Hishinuma, A.; Imai, Y.; Osawa, T 315

Short Communications

Tryptase and Kinin Generation: Tryptase from Human Mast Cells Does Not Activate Human

Urinary Prokallikrein Alter, S.C.; Yates, P.; Margolius, H.S.; Schwartz, L.B. . . 321

Studies on Alternaria Allergens. VI. Stability of the Allergen

Components of Alternaria tenuis Extracts under a Variety

of Storage Conditions

Vijay, H.M.; Young, N.M.; Bernstein, I.L 325

Human Lung Mast Cells: Distribution and Abundance of His-

tochemically Distinct Subpopulations

Shanahan, F.; MacNiven, I.; Dyck, N.; Denburg, J.A.;

Bienenstock, J.; Befus, A.D 329

Is the Surface Charge on Granulocytes Really Decreased fol

lowing Their Exposure to Chemotactic Factors?

McCarthy, D 332

Book Reviews 335

No. 4

Original Paper

Participation of Cell-Mediated Immunity in Allergic Broncho-

pulmonary Aspergillosis

Slavin, R.G.; Hutcheson, P.S.; Knutsen, A.P 337 
$\mathrm{c}^{1 / 8-M a c r o g l o b u l i n}-$ Kallikrein Potentiates Contact System Activity: Possible Effect in Asthma Freyria, A.-M.; Lasser, E.C.; Lyon, S.G.; Simon, R.A. . . 341

Inhibitory Effects of Oxatomide on Intracellular Ca Mobilization, Ca Uptake and Histamine

Release, Using Rat Peritoneal Mast Cells (with 1 color plate) Tasaka, K.; Akagi, M.; Mio, M.;

Miyoshi, K.; Nakaya, N. 348

Immunogenicity in Guinea Pigs and Tolerance in Grass Pollen-Sensitive Volunteers of EntericCoated Grass Pollen Allergens

Wheeler, A.W.; Henderson, D.C.; Youlten, L.J.F.; Al-Janabi, 1.1.; Hickman, B.E.; Taylor, I.H.; Moran, D.M. . 354

Botrytis cinerea: A Study of the Immunological Properties dur

ing Growth. Incidence of Antibodies against B. cinerea in a

Group of Patients with Aspergillosis

Kauffman, H.F.; van der Heide, S.; de Vries, K 359

Recovery Mechanisms from Experimental Allergic Encephalo-myelitis in Rats: Analyses by

Using Encephalitogenic T Cell Line

Namikawa, T.; Satoh, J.; Yamamura, T.; Sakai, K.; Kuni-

shita, T.; Tabira, T 366

Effects of Clonidine on the Dermal Inflammatory Cell Response of Experimental Toxic and Allergic Contact Reactions and Intradermal Hypersensitivity Anderson, CD.; Lindgren, B.R.; Andersson, R.G.G. ... 371

Effect of Cocaine on the Immune Response and Host Resistance in BALB/c Mice

Havas, H.F.; Dellaria, M.; Schiffman, G.; Geller, E.B.;

Adler, M.W 377

In vitro Translation of Messenger RNA from the House Dust

Mite Dermatophagoides pteronyssinus

Stewart, G.A.; Thomas, W.R 384

Recurrence of an Allergic Inflammation of Air-Pouch Type in

Rats and Possible Participation of Prostaglandin E2

Watanabe, M.; Ohuchi, K.; Tsurufuji, S 390

Effect of Whole-Body Irradiation on Precursor Frequency of

Autoantibody-Secreting Cells and Plaque-Forming Cells

Specific for Bromelain-Modified Erythrocytes

Errington, S.L.; Cox, K.0 398

Selection and Characterization of Monoclonal Antibodies against a Major Allergen in Dermatophagoides pteronyssi nus. Species-Specific and Common Epitopes in Three Der matophagoides Species

Horn, N; Lind, P 404

Defective Concanavalin A-Induced Suppression in Bancrof-

tian Filariasis

Vanamala, C.R.; Narayanan, P.R 410

Studies on Immunity in Hybridoma-Bearing Mice. A. Immune

Response to Antigens. II. Inhibition of Production of Anti-

Dinitrophenyl Antibodies in Mice Which Have Rejected

the B 53 Anti-Dinitrophenyl-Producing IgE Hybridoma

Yin, J.-Z.; Furusawa, S.; Hirano, T.; Ovary, Z 414 
Activity of Rat Peritoneal Eosinophils following Induction by Different Methods

Cook, R.M.; Musgrove, N.R.J.; Ashworth, R.F 423

Eosinophil- and Neutrophil-Mediated Injury of Human Lung

Fibroblast Cells

Cook, R.M.; Ashworth, R.F.; Musgrove, N.R.J 428

IgA Class and Subclass Thyroid Auto-Antibodies in Graves'

Disease and Hashimoto's Thyroiditis

Weetman, A.P 432

Irrelevant IgE Binding to Cellulose Discs in RAST

van Toorenenbergen, A.W.; Gerth van Wijk, R.; Dieges,

P.H.; Leijnse, B $\quad 436$

Book Reviews $\quad 440$

Books Received $\quad 440$

Author Index 441

Suppl. 1

From Antigen Presentation to Immunity and Allergy

Abstracts

Joint Meeting, Geneva, April 23-25, 1987

Editors: P.-H. Lambert, Geneva; J.-M. Dayer, Geneva;

D. Hoessli, Geneva

$((\mathrm{VI}=$ vakat $))$ 